\title{
IDENTIFYING A NATIONAL LEADERSHIP SKILLS TRAINING AND DEVELOPMENT STRATEGY FOR LEADERS WITHIN SECTOR EDUCATION TRAINING AUTHORITIES (SETAS)
}

\author{
FLORUS PJ PRINSLOO \\ AH LATEGAN \\ Department of Human Resource Management \\ University of Johannesburg
}

\begin{abstract}
Through a literature survey and a qualitative survey of the views of a selected sample of key role-players in the implementation of the South African Skills Development Strategy a number of transformational leadership competencies were identified that influence the effectiveness of Sector Education and Training Authorities (SETAs). A subsequent quantitative survey of the views of a random sample of SETA managers and Board members ranked the identified leadership competencies in terms of relevance to and importance for effectiveness of SETA leadership teams. The research results were applied to propose a learning programme strategy to develop the identified transformational leadership competencies amongst SETA leaders.
\end{abstract}

\section{OPSOMMING}

In 'n literatuuroorsig en 'n kwalitatitatiewe opname van die sienings van 'n geselekteerde steekproef onder sleutelrolspelers in die uitvoering van die Suid-Afrikaanse Vaardigheidsontwikkelingstrategie is ' $n$ aantal transformerende leierskapsvaardighede geîdentifiseer wat die effektiwiteit van Sektorale Onderwys- en Opleidingsgesagliggame (SOOGe) beînvloed. 'n Daaropvolgende kwantitatiewe opname van die sienings van 'n ewekansige steekproef van SOOG-bestuurders en -raadslede het die geîdentifiseerde leierskapsvaardighede op, onderskeidelik, 'n toepaslikheids- en 'n belangrikheidskaal vir SOOG-leierskapspanne getakseer. Die navorsingsresultate is toegepas om 'n leerprogramstrategie voor te stel om die geiddentifiseerde transformerende leierskapsvaardighede onder SOOG-leiers te ontwikkel.

The cliche that "change is the only constant" continues to accurately describe the world of work and economics in a competitive global environment. To stay with and cope with change all entities in a national economy have a need to continually re-skill their people (Heller,1998, p.5)

To meet this need in South Africa, the Minister of Labour adopted and presented the National Skills Development Strategy to the citizens of the country in February 2001 as a solution to the problem of re-skilling (Department of Labour, 2001).

The sub-title of the strategy document - Skills for Productive Citizenship for All - summarises the vision for the future. The mission statement of the strategy document directly addresses the need that South Africa has for getting to grips with its skills deficiencies:

"To equip South Africa with the skills to succeed in the global market and to offer opportunities to individuals and communities for self advancement to enable them to play a productive role in society." (Department of Labour, 2001, p.4)

To implement the National Skills Development Strategy the Government promulgated the Skills Development Act, 1988 (Act No. 97 of, 1998). On 20 March 2000 the Minister of Labour established 25 sector education and training authorities (SETAs) in designated economic sectors in terms of Section 9(1) of the Act. The purpose of SETAs is to help implement the National Skills Development Strategy and to increase the skills of people in their designated sector.

\section{The effectiveness of SETAs}

Since March 2000 to date, the success record of the proposed solution to develop skills in South Africa has been mixed. Over the last few years media reports have mirrored successes and failures. The Star carried an upbeat series of articles in October 2001 (Star, 2001) that gave the

Requests for copies should be addressed to: A. Lategan, andries@mail.ngo.za impression that the new system is ready for successful implementation. In contrast, the same newspaper reported in February 2002 that "Government is going to get tough with companies that are not training their employees, thus leaving millions of Rand in skills development funds unspent" (Star, 2002, p.27).

A Business Day article under the headline "Some SETAs work, others are a disaster" (Business Day, 2002) quotes Sam Morotoba the Exuctive Officer of the National Skills Authority as saying that "leadership disputes have emerged as the common element in the SETAs where problems have been identified". This comment attributed to an individual involved at the highest level with the process seems to point to problems around leadership competencies within SETAs as an important contributing cause of implementation failures.

An understanding of the relation between leadership competence and SETA effectiveness is clearly in the national interest. This paper reports on a study that investigated three related questions that may be asked in this regard: "how important is leadership competence as a factor influencing SETA effectiveness?"; "what are the leadership competencies relevant to and important for SETA effectiveness?"; and "how can the required SETA leadership competencies be developed?".

\section{Theoretical framework and approach}

SETAs are statutory bodies established in terms of an Act of Parliament. However, they function under the authority of a board that is made up of elected employer and trade union representatives from the relevant sectors, thereby making the SETA more relevant and responsive to the needs of the customers within the different sectors. In this way SETAs are similar to any organisation that operates and serves a specifically demarcated market segment.

The approach in this study was thus to locate the analysis of leadership competencies within the current theoretical 
understanding of organisational dynamics. The organisational dynamics model developed by Veldsman (2002) was adopted as the appropriate theoretical framework for this purpose.

Veldsman (2002) views organisations operating in the postmodern world as a "network of dynamically interdependent nodes within a force field of effects and counter-effects which must be fused". He describes each one of these nodes or contextual factors as follows:

- Ecosphere - the setting in which an organisation is embedded such as markets, clients, products, services, suppliers, communities and the broader society.

- Strategic Intent - sum total of vision, missions, values and goals of organisation

- Leadership - activities related to future creation, actualisation and continuity in an organisation

- Culture - shared ways if seeing, interpreting and doing

- Architecture - the shape, structure, roles, systems and practises of an organisation

- Resources - means to attain ends such as money, facilities, technology, knowledge, skills.

The departure point for this study was that the anecdotal evidence from newspaper reports referred to above gives a strong indication that leadership - defined as activities related to future creation, actualisation and continuity in an organisation - should be ranked as the most critical independent variable or contextual factor influencing SETA effectiveness in relation to the others nodes in the Veldsman model.

\section{RESEARCH AIMS}

The primary aim of this study was to identify transformational leadership competencies that are applicable, important and relevant to the effectiveness of SETAs in South Africa. The final aim was to apply the findings in the first part of the study to arrive at recommendations for a strategy to develop the identified transformational leadership competencies amongst SETA leaders.

\section{RESEARCH DESIGN}

\section{Research approach}

The ontology of the qualitative research strategy was based on grounded theory. The research is the first of its kind due to the fact that SETAs are very new organizational structures within the country, having been established by law in March 2000. A set of transformational leadership competencies from a literature review were related to the functions of the SETA as described in the law. This formed the basis for observations from a selected group of persons through an interview and discussion guide. This approach resulted in a set of applicable transformational leadership competencies linked to SETA functions being identified inductively.

The epistemology of the qualitative approach thus has its foundation on transformational leadership competencies within the scope of what is applicable to the functions of a SETA. The validity of the competencies was confirmed through the interview process to check for applicability of each transformational competency in relation to the functions of the SETA.

\section{Research methodology}

Participants in the study

Seven subject matter experts in the field of South African skills development and SETA related issues were selected for interviews and discussions. These included employees within the Department of Labour who have regulatory oversight over the SETAs, a members of the National Skills Authority that advise the Minister of Labour on skills development, employees of the South African Qualifications Authority responsible for quality of skills development programmes and private skills development consultants who work on a daily basis with the SETAs.

The group selected consisted of very experienced individuals in the 40 to 55 age group, all at senior executive levels within their organizations.

\section{Data gathering methods}

Data was gathered using a structured interview process (an interview schedule) based on the use of carefully designed interview and discussion guide.

\section{Procedure of gathering the data}

The procedure to collect the data was carefully controlled and followed the following sequence:

- An interview and discussion guide was developed to ensure that each interview followed the same process, thereby ensuring consistency of data gathering.

- Each interviewee was contacted telephonically or in person to explain the process and request the person to participate.

- The interview and discussion guide was e-mailed or faxed to the interviewee who completed it to the best of their ability and retuned to the researcher.

- The researcher reviewed the interviewee's comments and then contacted the interviewee telephonically or in person or by e-mail to check and confirm the comments of the interviewee.

\section{Treatment of the data}

All the data was first captured on the interview and discussion guides and analysed against the criteria included on the guide. The data was categorised into three sections:

First section related to the competencies that were applicable to SETA leaders. Through the review of the comments from interviewee each competency was found to be not applicable, partially applicable or very applicable.

The second section related to contextual factors within SETAs and how important each factor was in relation to transformational leadership competencies.

The third section was based on subjective comments from the interviews. A General trend analysis was used to pick up reoccurring themes in the data submitted.

\section{RESULTS AND DISCUSSION}

\section{Survey of leadership theories and competencies}

Following van Maurik (2001), four generations of leadership theories developed in the latter part of the twentieth century may be identified:

- Trait Theories based on the premise that all leaders had certain basic "traits" in their personalities.

- Behavioural Theories based on the assumption that leadership could be taught and that good leadership was a matter of adopting the right sort of behaviour.

- Contingency Theories based on "transactions" between leader and followers. Leadership styles which are "contingent or dependent" on the situation and transactions between leaders and followers.

- Transformational Theories based on the idea of the leader as an agent of change.

The transformational leadership competencies identified in the fourth generation of leadership theories are critical for 
SETA leaders. However none of the insights of the other generations can be completely ignored, especially the transactional generation. Table 1 summarises generic leadership competencies from a literature review of the above leadership theories.

\section{TABLE 1}

SUMMARY OF GENERIC LEADERSHIP COMPETENCIES

Trait Theories (van Maurik, 2001)

- Ideological security - strong sense of conviction you are right

- Moral courage - could stand alone if required

- Constancy - could not easily be turned

- An iron will - could go things alone

- A low need for love - respect was more important than love

Behavioural Theories (van Maurik, 2001)

- Man has a will

- Man is open to good and evil

- Situation drives man

- Reason motivates man

- Interdependence is man's basic mode of interaction

- Interaction is man's social unit of importance

- Objective best describes man's view of man

Transactional \& Transformational Theories (van Maurik, 2001)

\section{Transactional Leadership}

Clarify goals and objectives to

obtain immediate results

Create structures and processes for control

Solve problems

Maintain and improve the current situation

Plan, organize and control Guard and defend the culture

Power comes from position and authority in the organisation
Transformational Leadership

Establish a long term vision

Create a climate of trust

Empower people to control themselves; manage problem solving

Change the current situation

Coach and develop people Challenge and change the culture

Power comes from influencing a network of relationships
De Kets Vries (2001)

- Surgency - people with a more assertive character, strong achievement orientation

- Sociability - people with the trait of extroversion, people's people

- Receptivity - people who are open to new ideas and experiences

- Agreeableness - people who are flexible, likable, positive people

- Dependability - people who are conscientious, who deliver

- Analytical intelligence - people with more than average intelligence, think strategically

- Emotional intelligence - people who manage own and read other's emotions

Veldsman (2002)

- Wisdom - to know when, how, and with whom to do what

- $\quad$ Ethical competence - act consistently, coherently from moral convictions

- Personal competence - qualities of a person enabling a style of conduct

- Transformational competence - change the existing into something new

- Transactional competence - build, maintain and improve existing systems

- Technical competence - use knowledge, expertise and skills in a technical domain

- Capacity to learn - distil knowledge \& wisdom from experience and change

- Contextual competence - handle the complexity of a situation at the appropriate level.

\section{Madi (2000)}

- Build a sense of mission - be certain of where you are going, set goals, actively promote the mission
- Be a conqueror or be apprenticed to a conqueror - look for and approach mentors, use books as mentors.

- Mission is more important than convention - focus on the mission, achieve it at all costs

- Lead the charge from the front - stick you neck out, dictate the direction that the company must follow

- Build a fanatical team - surround yourself with people that will help you make your dream come true

- Be a good strategist or get one - plan you work and then work your plan

- Go where angels fear to tread - courage is needed for any kind of leadership, take up challenges

- Know the battlefield better than the enemy - know the industry, know the market, know the competitors

- Be obsessed with world-class technologies - Use the best tools you can afford to grow the business

- Never believe your own PR - never think you have arrived, always seek ways to improve

SETA functions and leadership competencies

The functions of the SETAs are listed in Chapter 3, Section 10 of the Skills Development Act (Republic of South Africa , 1998). These functions were linked to the most relevant generic leadership competencies identified in the literature search as summarised in Table 1. The linkages are shown in Table 2.

\section{Transformational leadership competencies applicable to} SETAs

A qualitative research approach was used to contextualise the generic competencies to the South African SETA leaders. This qualitative approach was implemented through a series of open ended interviews with seven carefully selected individuals involved with SETAs and the implementation of the National Skills Development Strategy.

From the interviews conducted the competencies that were identified as Applicable are shown in Table 3.

The interviewees also indicated that the other contextual factors described by Veldsman (2002) have to be considered, not only leadership competencies. However, the interviewees recommended that the contextual factors should be explained in a simpler manner for participants in further research. Such simpler descriptions are shown in Table 4.

The applicable transformational leadership competencies and contextual factors were used in a questionnaire based quantitative research process to establish importance and relevance of each competence and contextual factor to SETA leaders.

The research sample selected was four SETA managers per SETA and four Board Members per SETA, a total of eight persons per SETA. The total number of research questionnaires that was sent out for the survey amounted to two hundred. This questionnaire that had been designed was piloted at one specifically selected SETA. Each person in the pilot study was asked to complete the questionnaire and comment on whether it was firstly understandable and secondly not too time consuming to complete. Seven out of the eight persons approached returned the questionnaire with favourable and positive comments. The primary quantitative research process was implemented from 21 January 2003 until 28 March 2003.

\section{Results}

The total number of questionnaires recovered amounted to a total of 35 a $17,5 \%$ recovery rate. An analysis of the returns from SETAs is shown in Figure 1. 
TABLE 2

LINKING SETA FUNCTIONS TO LEADERSHIP COMPETENCIES

\begin{tabular}{|c|c|c|c|}
\hline No. & Section of Act & Function Description & Related Leadership Competencies \\
\hline 1 & 10.(1)(a) & $\begin{array}{l}\text { A SETA must develop a sector skills plan within the framework of the } \\
\text { national skills development strategy }\end{array}$ & $\begin{array}{l}\text { Technical Competence } \\
\text { Build a sense of mission, develop analytical intelligence, receptivity }\end{array}$ \\
\hline 2 & 10.(1)(b)(i) & $\begin{array}{l}\text { A SETA must implement its sector skills plan by establishing } \\
\text { learnerships }\end{array}$ & $\begin{array}{l}\text { Transformational Competence } \\
\text { Mission is more important than convention, tenacity, moral courage }\end{array}$ \\
\hline 3 & 10.(1)(b)(ii) & $\begin{array}{l}\text { A SETA must implement its sector skills plan by approving } \\
\text { workplace skills plans }\end{array}$ & $\begin{array}{l}\text { Ethical Competence } \\
\text { Create structures and processes for control, solve problems }\end{array}$ \\
\hline 4 & 10.(1)(b)(iii) & $\begin{array}{l}\text { A SETA must implement its sector skills plan by allocating grants } \\
\text { in the prescribed manner to employers, education and training } \\
\text { providers and workers }\end{array}$ & $\begin{array}{l}\text { Technical Competence } \\
\text { Create structures and processes for control, solve problems }\end{array}$ \\
\hline 5 & 10.(1)(b)(iv) & $\begin{array}{l}\text { A SETA must implement its sector skills plan by monitoring education } \\
\text { and training in its sector }\end{array}$ & $\begin{array}{l}\text { Transactional Competence } \\
\text { Create structures and processes for control, be obsessed with world class } \\
\text { technologies }\end{array}$ \\
\hline 6 & 10.(1)(c)(i) & $\begin{array}{l}\text { A SETA must promote learnerships by identifying workplaces for } \\
\text { practical experience }\end{array}$ & $\begin{array}{l}\text { Transformational Competence } \\
\text { Surgency and sociability, lead the charge from the front }\end{array}$ \\
\hline 7 & 10.(1)(c)(ii) & $\begin{array}{l}\text { A SETA must promote learnerships by supporting the development } \\
\text { of learning materials }\end{array}$ & $\begin{array}{l}\text { Contextual Competence } \\
\text { Be a good strategist or get one, plan, organize and control }\end{array}$ \\
\hline 8 & 10.(1)(c)(iii) & $\begin{array}{l}\text { A SETA must promote learnerships by improving the facilitation } \\
\text { of learning }\end{array}$ & $\begin{array}{l}\text { Transactional Competence } \\
\text { Create structures and processes for control }\end{array}$ \\
\hline 9 & 10.(1)(c)(iv) & $\begin{array}{l}\text { A SETA must promote learnerships by assisting in the conclusion } \\
\text { of learnership agreements }\end{array}$ & $\begin{array}{l}\text { Transformational Competence } \\
\text { Build a fanatical team, go where angels fear to tread }\end{array}$ \\
\hline 10 & 10.(1)(d) & A SETA must register learnership agreements & $\begin{array}{l}\text { Technical Competence } \\
\text { Create structures and processes for control }\end{array}$ \\
\hline 11 & 10.(1)(e) & $\begin{array}{l}\text { A SETA must within a week from its establishment, apply to the } \\
\text { South African Qualifications Authority for accreditation as a body }\end{array}$ & $\begin{array}{l}\text { Technical Competence } \\
\text { Capacity to learn, analytical intelligence, tenacity }\end{array}$ \\
\hline
\end{tabular}

12 10.(1)(f) A SETA must collect and disburse the skills development levies in its sector

13 10.(1)(g)(i) A SETA must liaise with the National Skills Authority on the national skills development policy

14 10.(1)(g)(ii) A SETA must liaise with the National Skills Authority on the national skills development strategy

15 10.(1)(g)(iii) A SETA must liaise with the National Skills Authority on its sector skills plan

16 10.(1)(h)(i) A SETA must report to the Director General on its income and expenditure

17 10.(1)(h)(ii) A SETA must report to the Director General on the implementation of its sector skills plan

18 10.(1)(i)(i) A SETA must liaise with the employment services of the department and any education body established under any law regulating education in the Republic to improve information about employment opportunities

19 10.(1)(i)(ii)

A SETA must liaise with the employment services of the department and any education body established under any law regulating education in the Republic to improve information between education and training providers and the labour market

20 10.(1)(j)

A SETA must appoint staff necessary for the performance of its functions

21 10.(1)(k) A SETA must perform any other duties imposed by this Act or consistent with the purposes of this Act

22 10.(2)(a) A SETA has all such powers as are necessary to enable it to perform its duties referred to in subsection(1)

23 10.(2)(a)

A SETA has the other powers conferred on the SETA by this Act

24 10.(3)

A SETA must perform its functions in accordance with this Act and its constitution

Ethical Competence

Solve problems, create structures and processes for control

Transformational Competence

Dependability

Transformational Competence

Dependability

Transactional Competence

Solve problems, plan organise and control

Ethical Competence

Dependability, analytical intelligence

Transactional Competence

Create structures and processes for control

Transactional Competence

Agreeableness, dependability, create structures and processes for contro

Transactional Competence

Agreeableness, dependability, create structures and processes for contro

Ethical Competence

Build a fanatical team

Technical Competence

Analytical intelligence

Transformational Competence

Establish a long term vision

Ethical Competence

Create structures and processes for control

Ethical Competence

Create structures and processes for control

The percentage of questionnaires returned by SETA is shown in Table 5 .

A total of fifteen out of the current twenty five SETAs responded. Research results thus include input from $60 \%$ of the SETAs. This research result gives validity to the research since more than $50 \%$ of the SETAs had input to the research.

The research findings and the conclusions reached from the research findings will as a result of the $86 \%$ input from SETA Managers be considered more the views of SETA Management members rather than the views of SETA Board members.
The research showed that SETAs mostly employed between 21-40 full time employees countrywide. Figure 2 illustrates this.

An analysis of the respondents to the survey shows the gender race and ages breakdown of the SETA Management members that responded to the survey. Figures 3,4,5 show these breakdowns.

Table 6 shows the percentages of respondents that ranked each transformational leadership competency for SETA Managers as very relevant and very important.

As may be expected, the correlation coefficient between the two sets of data shown in Table 6 is $+0,946$ which is close to a perfect correlation of +1 
TABLE 3

\section{CONTEXTUALISED TRANSFORMATIONAL LEADERSHIP COMPETENCIES}

Transformational Leadership Competency

Building a sense of mission in all SETA Stakeholders

Developing the analytical skills of your staff

Creating an openness to new ideas from others

Creating structures and processes for control

Developing problem solving skills of your staff

Having tenacity

Having moral courage

Developing the assertiveness of your staff

Developing the social skills of your staff

Developing strategic planning skills in yourself

Developing organising capacity in yourself

Building a dynamic team

Developing the capacity to learn in yourself and your staff

Creating an agreeable spirit among your staff

Developing staff that are dependable

TABLE 4

CONTEXTUAL FACTORS THAT ARE TO BE CONSIDERED IN QUANTITATIVE SURVEY

\begin{tabular}{lll}
\hline Factor & Veldsman Description & Simplified Description \\
\hline 1 & Ecosphere & External Environment \\
2 & Strategic Intent /Leadership & Leadership competencies \\
3 & Culture & Organisational culture \\
4 & Architecture & Organisational structure \\
5 & Resources & Resources \\
\hline
\end{tabular}

TABLE 5

Percentage of questionnaires Returned by SETAs

Type of SETAstakeholder

\begin{tabular}{lcr}
\hline & Count & $\%$ \\
\hline BANKSETA & 1 & 2,9 \\
CETA & 1 & 2,9 \\
CHIETA & 8 & 22,9 \\
DIDTETA & 2 & 5,7 \\
ETDP-SETA & 6 & 17,1 \\
FASSET & 4 & 11,4 \\
FOODBEV & 1 & 2,9 \\
INSETA & 2 & 5,7 \\
ISETT & 1 & 2,9 \\
MQA & 1 & 2,9 \\
SERVICES & 2 & 5,7 \\
SETASA & 1 & 2,9 \\
TETA & 1 & 2,9 \\
THETA & 3 & 8,6 \\
W\&RSETA & 1 & 2,9 \\
Total & 35 & 100,00 \\
\hline
\end{tabular}

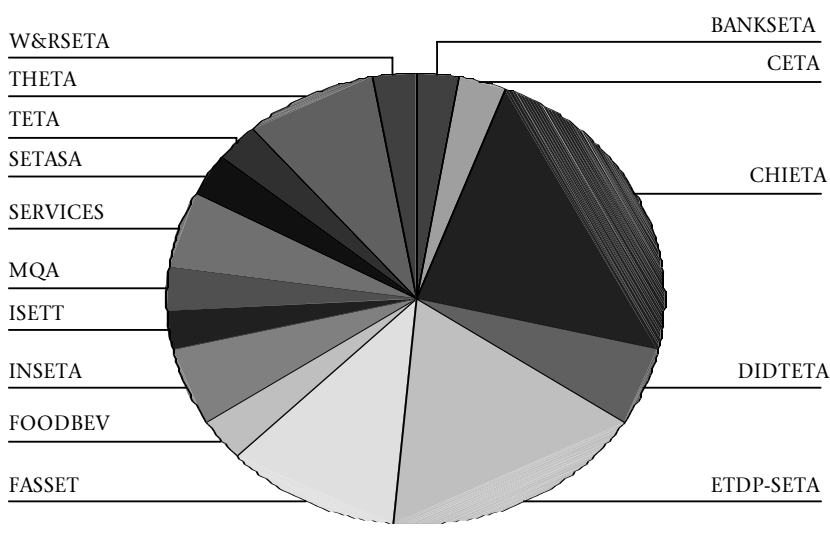

Figure 1: Analysis of questionnaires received from SETAs

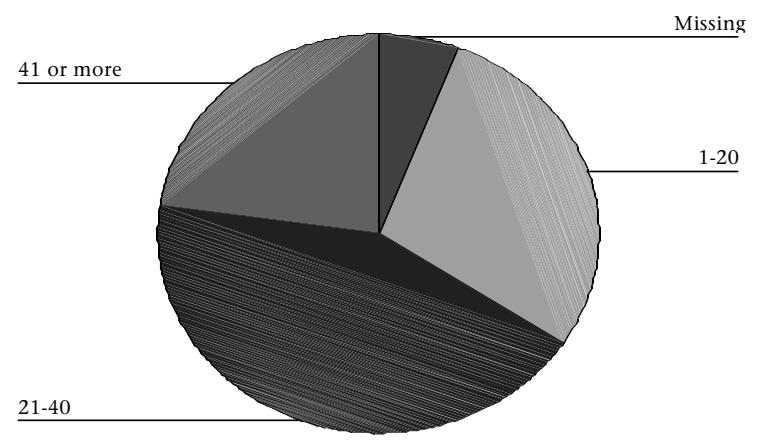

Figure 2: Number of full time employees per SETA

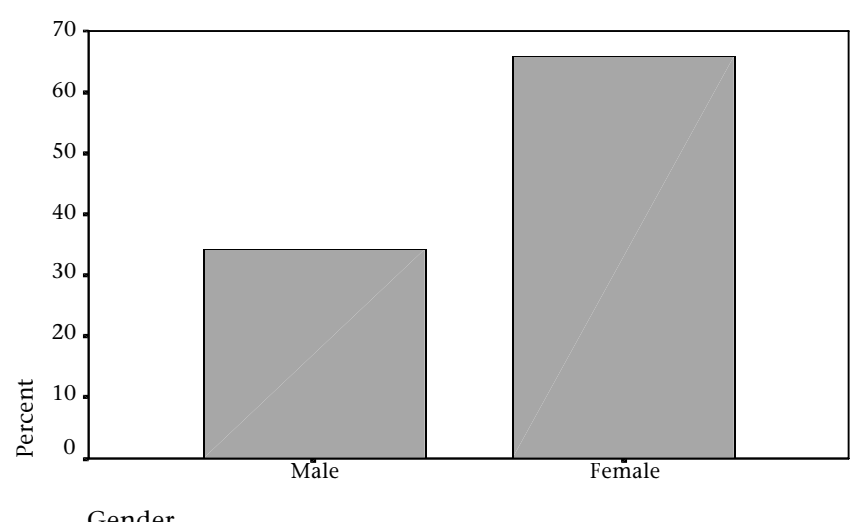

Figure 3: Gender breakdown of SETA Managers

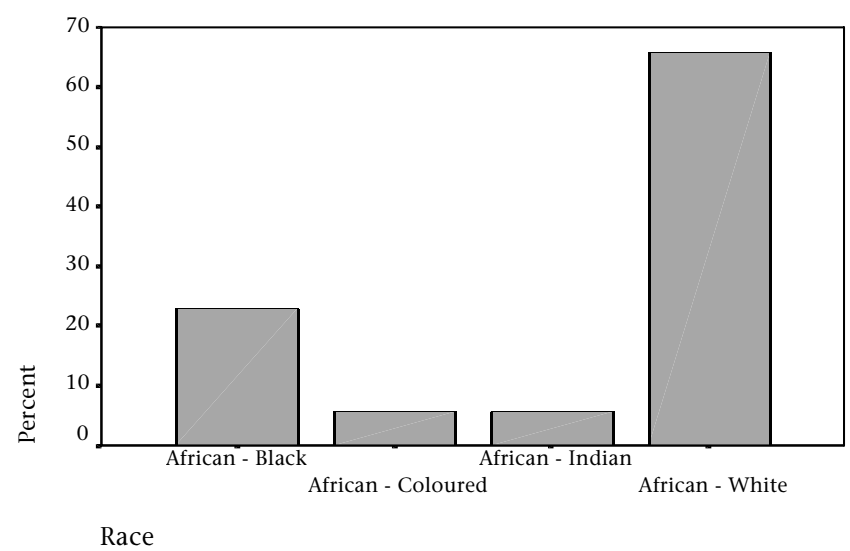

Figure 4: Race breakdown of SETA Managers 


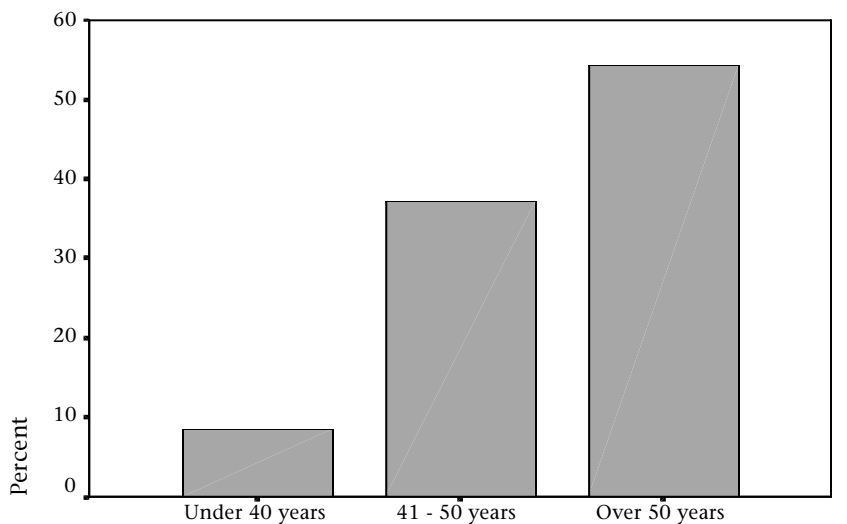

Age

Figure 5: Age breakdown of SETA Managers

TABLE 6

VERY RELEVANT/IMPORTANT TRANSFORMATIONAL LEADERSHIP COMPETENCIES

\begin{tabular}{|c|c|c|}
\hline SETA Manager Leadership Competency & $\begin{array}{l}\% \text { Of } \\
\text { respondents } \\
\text { that said } \\
\text { VERY } \\
\text { Relevant }\end{array}$ & $\begin{array}{c}\% \text { Of } \\
\text { respondents } \\
\text { that said } \\
\text { VERY } \\
\text { Important }\end{array}$ \\
\hline Building a sense of mission in all SETA Stakeholders & rs 54,3 & 63,6 \\
\hline Developing the analytical skills of your staff & 28,6 & 27,3 \\
\hline Creating an openness to new ideas from others & 48,6 & 34,4 \\
\hline Creating structures and processes for control & 65,7 & 60,6 \\
\hline Developing problem solving skills of your staff & 40,0 & 33,3 \\
\hline Having tenacity & 32,4 & 28,1 \\
\hline Having moral courage & 42,9 & 52,9 \\
\hline Developing the assertiveness of your staff & 17,1 & 17,6 \\
\hline Developing the social skills of your staff & 14,3 & 8,8 \\
\hline Developing strategic planning skills in yourself & 65,7 & 73,5 \\
\hline Developing organising capacity in yourself & 45,7 & 50,0 \\
\hline Building a dynamic team & 71,4 & 72,7 \\
\hline $\begin{array}{l}\text { Developing the capacity to learn in yourself \& } \\
\text { your staff }\end{array}$ & 52,9 & 55,9 \\
\hline Creating an agreeable spirit among your staff & 30,3 & 32,4 \\
\hline Developing staff that are dependable & 51,4 & 50,0 \\
\hline
\end{tabular}

The close correlation between relevant and important competencies allows for an accurate ranking of the competencies from MOST relevant \& important to LEAST relevant \& important. Using the VERY important as primary index the competencies are ranked in Table 7.

Leadership Competency is only one of five contextual factors that impinge upon the effectiveness of any organisation. During the research process the other four factors were also evaluated by the SETA Managers. The research analysed if the other factors were as important, more important or less important than leadership competencies. The research results are shown in Figure 6.
The middle section of each bar in Figure 6 is significantly larger than the bottom or top sections. The implication is that other contextual factors are as important as leadership competencies within SETAs. A closer look at the results indicates that the External Environment and Resources are considered more important than Organisational Culture and Organisational Structure. This is confirmed in the percentages shown in Table 8 .

TABLE 7

RANKING TRANSFORMATIONAL LEADERSHIP COMPETENCIES

\begin{tabular}{cl}
\hline $\begin{array}{c}\text { Ranking } \\
\text { Most Important } / \\
\text { Relevant } \\
\begin{array}{c}\text { Least Important/ } \\
\text { Relevant }\end{array}\end{array}$ & $\begin{array}{l}\text { SETA Manager } \\
\text { Transformational Leadership Competency }\end{array}$ \\
\hline $73,5=1$ & Developing strategic planning skills in yourself \\
$72,7=2$ & Building a dynamic team \\
$63,6=3$ & Building a sense of mission in all SETA Stakeholders \\
$60,6=4$ & Creating structures and processes for control \\
$55,9=5$ & Developing the capacity to learn in yourself and \\
$52,9=6$ & your staff \\
$50,0=7$ & Having moral courage \\
$50,0=7$ & Developing organising capacity in yourself \\
$34,4=9$ & Creating an openness to new ideas from others \\
$33,3=10$ & Developing problem solving skills of your staff \\
$32,4=11$ & Creating an agreeable spirit among your staff \\
$28,1=12$ & Having tenacity \\
$27,3=13$ & Developing the analytical skills of your staff \\
$17,6=14$ & Developing the assertiveness of your staff \\
$8,8=15$ & Developing the social skills of your staff \\
\hline
\end{tabular}

Contextual factors in relation to keadership competencies

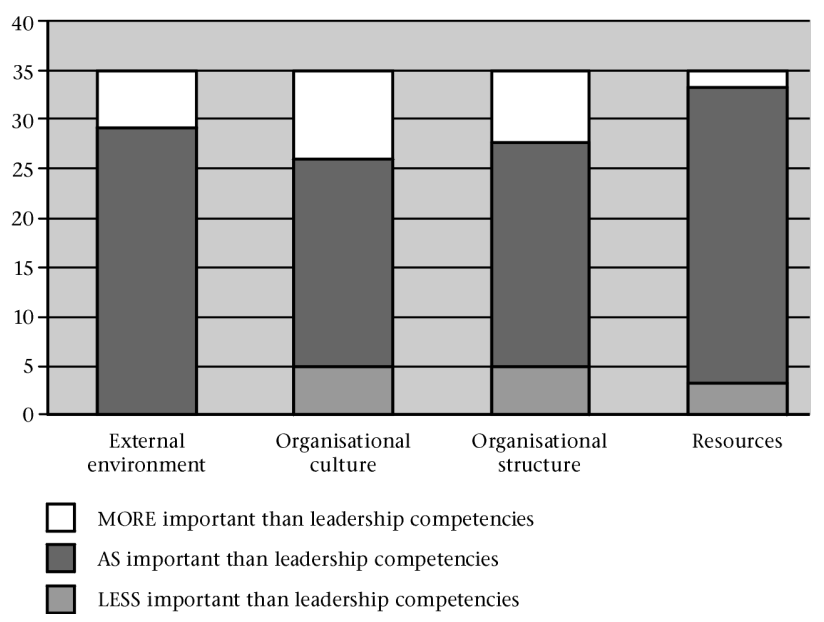

Figure 6: Importance of transformational leadership competencies in relation to other organisational contextual factors from responses of SETA Managers

TABLE 8

OTHER CONTEXTUAL FACTORS COMPARED TO LEADERSHIP COMPETENCIES

\begin{tabular}{|c|c|c|c|c|c|c|c|c|}
\hline & \multicolumn{2}{|c|}{ Eternal Environment } & \multicolumn{2}{|c|}{ Organisational Culture } & \multicolumn{2}{|c|}{ Organisational Structure } & \multicolumn{2}{|c|}{ Resources } \\
\hline & Count & $\%$ & Count & $\%$ & Count & $\%$ & Count & $\%$ \\
\hline LESS important than Leadership Competencies & & & 5 & 14,3 & 6 & 17,1 & 4 & 11,4 \\
\hline \multirow[t]{3}{*}{ AS important than Leadership Competencies } & 28 & 80,0 & 22 & 62,9 & 22 & 62,9 & 29 & 82,9 \\
\hline & 7 & 20,0 & 8 & 22,9 & 7 & 20,0 & 2 & 5,7 \\
\hline & 35 & 100,0 & 35 & 100,0 & 35 & 100,0 & 35 & 100,0 \\
\hline
\end{tabular}


TABLE 9

Percenatge analysis of importance of all contextual factors

\begin{tabular}{|c|c|c|c|c|c|c|c|c|c|c|}
\hline & \multicolumn{2}{|c|}{ Eternal Environment } & \multicolumn{2}{|c|}{ Organisational Culture } & \multicolumn{2}{|c|}{ Organisational Structure } & \multicolumn{2}{|c|}{ Resources } & \multicolumn{2}{|c|}{ Leadership Competencies } \\
\hline & Count & $\%$ & Count & $\%$ & Count & $\%$ & Count & $\%$ & Count & $\%$ \\
\hline Most important & 10 & 28,6 & 5 & 14,3 & 1 & 2,9 & 3 & 8,6 & 18 & 51,4 \\
\hline Second most important & 4 & 11,4 & 10 & 28,6 & 6 & 17,1 & 6 & 17,1 & 13 & 37,1 \\
\hline Third most important & 6 & 17,1 & 12 & 34,3 & 9 & 25,7 & 8 & 22,9 & 1 & 2,9 \\
\hline Fourth most important & 7 & 20,0 & 4 & 11,4 & 7 & 20,0 & 13 & 37,1 & 1 & 2,9 \\
\hline Least important & 8 & 22,9 & 4 & 11,4 & 12 & 34,3 & 5 & 14,3 & 2 & 5,7 \\
\hline Total & 35 & 100,0 & 35 & 100,0 & 35 & 100,0 & 35 & 100,0 & 35 & 100,0 \\
\hline
\end{tabular}

To further analyse this comparison between leadership competencies and other contextual factors, the respondents were also requested to rank each contextual factor including leadership competencies in importance. This research result is shown in Figure 7.

By referring to the actual percentage data as shown in Table 9 below, leadership competencies are considered most important by $51,4 \%$ of the respondents and second most important by $37.1 \%$ of the respondents. That totals $88,5 \%$ of respondents that believe that leadership competencies are most or second most important of the contextual factors in a SETA. External environment and organisational culture are also important while organisational structure and resources were considered less important.

\section{Discussion}

The research validates the hypothesis that transformational leadership competency is currently the most important of the SETA contextual factors.

Contextual factors ranked in importance

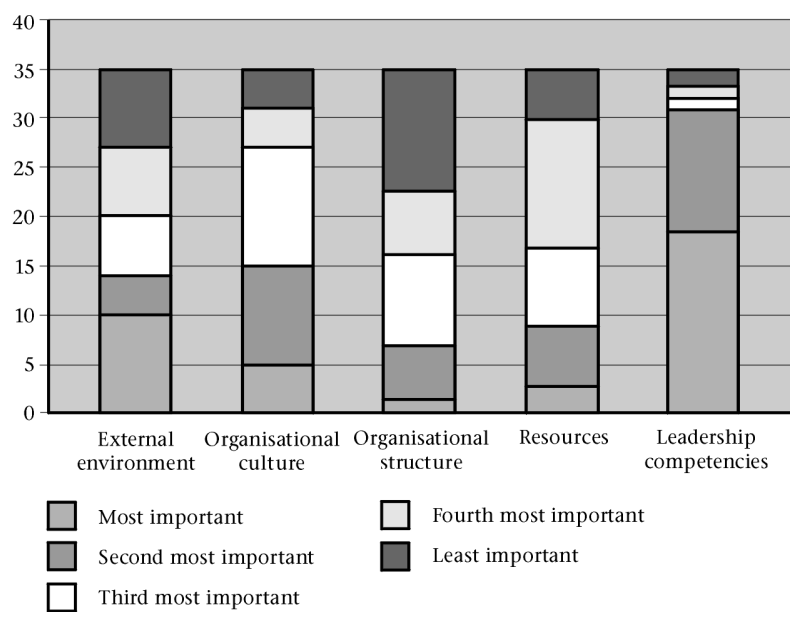

Figure 7: All contextual factors ranked in importance

More than $50 \%$ of the SETA Management members showed interest and responded to this survey. This indicates that there is interest in and acceptance of the need to develop a strategy for leaderships skills training and development among SETA Management members. A specific strategy needs to be urgently developed, agreed upon by SETA Managers and SETA Board Members and implemented by the SETA Managers forthe development of leadership competencies for all SETA Managers.

Very few SETA Board members showed interest in this survey at all. Board members appear not concerned with the development of leadership competencies of SETA Management members.
SETAs have small numbers of employees in relation to the nature and enormity of their task. This appears to indicate that SETAs are finding it hard to employ people that they require. It is possible though that some of the SETAs are using an outsourcing model for implementing skills development in their sectors and not employing full time staff. A strategy for the leadership competency development for SETA Management members must include developing the SETA Leader competency for capacitating existing fulltime SETA staff or identifying competent service providers for outsourced activities.

Race and possible age imbalances will need to be redressed among SETA Management members when the legislative moderating factors such as employment equity are considered. Gender imbalance is less of a problem. A strategy for the leadership competency development for SETA Management members must include competencies of SETA leaders for developing younger black males to become competent SETA Managers. This relates to the organisational transformational needs of an organisation that include the necessity to consider situational factors in South Africa. This could indicate the need for a mentoring programme within SETAs.

A close correlation exists between very relevant and very important leadership competencies for SETA Managers. This allows for an accurate ranking of the leadership competencies in terms of most critical to least critical. A strategy for the leadership competency development for SETA Management members must address the competencies as listed in the priority sequence in Table 4. This can be achieved through a structured learning programme that requires SETA Managers to develop competencies in the same sequence as listed in Table 7.

Leadership competencies are clearly considered more important than other contextual factors, but others should not be ignored. SETA Managers see the need for the development of transformational leadership competencies as more important than other contextual factors. A strategy for the leadership competency development for SETA Management members must focus on the development of leadership competencies primarily, but must consider the contextual factors of the external environment and organisational culture as analysed in Figure 8 and Table 9.

\section{CONCLUSION}

In conclusion the research study for Identifying a national leadership skills training and development strategy for leaders within sector education training authorities (SETAs) clearly points to the need for a carefully planned structured learning programme for developing leadership competencies of SETA leaders. 
Such a learning programme can take the format of a formal institutionally based qualification or a more vocationally based learnership programme. Either learning process will need to be carefully assessed through actual workplace competency based assessment.

A structured learning programme for all SETA leaders (Board members and Managers) should be developed and implemented within the next twelve to eighteen months for all SETAs to develop leaders with the specific transformational leadership competencies in the priority order as sequenced in Table 7 of this report.

The learning programme should be developed and implemented through a process that involves and commits all SETA leaders to the process. The learning programme and process will need to include the following critical factors:

- develop SETA staff capacity

- implement and achieve national employment equity targets

- Link development of leadership competencies to development of other related contextual factors as listed in Figure 16

- allow leaders within specific SETAs to develop at their own pace.

\section{REFERENCES}

Business Day (2002). National News, 29 April.

City Press (2003). Minister deplores SETAs sorry state, 8 March.

Department of Labour. Learnerships, Transforming people, transforming South Africa. Pretoria: Department of Labour.

Department of Labour (2001). The National Skills Development Strategy - Skills for productive citizenship for all. Pretoria: Department of Labour.

Heller, R. (1998). Managing Change. London: Dorling Kindersley Limited.

Kets de Vries, M. (2001). The leadership mystique, a user's manual for the human enterprise. Financial Times, Prentice Hall.

Madi, P.M. (2000). Leadership lessons from Emperor Shaka Zulu the Great. Johannesburg: Knowledge Resources.

Republic of South Africa (1998). Skills Development Act. No 97 of 1998, Government Gazette, Volume 401, No. 19240.

Star (2001). Business Report. 4 October, pp.6 -9.

Star (2002). Parliamentary Briefings, 4 February 4.

Sunday Times (2002). Business Times Survey on SETAs, 21April.

Van Maurik, M. (2001). Writers on Leadership. city??: Penguin Business.

Veldsman, T.H. (2002). Into the people effectiveness arena -navigating between chaos and order. Johannesburg: Knowledge Resources. 